\title{
Muhammadiyah and the Issue of Liberalism
}

\author{
Mahsun $^{1 *}$ \\ ${ }^{1}$ Faculty of Teacher Training and Education, Universitas Muhammadiyah Surabaya, Surabaya, Indonesia \\ "Corresponding author. Email: mahsunjayady@yahoo.co.id
}

\begin{abstract}
the issue of liberalism has been talked over in the perspective of Islam and Muhammadiyah organization is no exception. This study is therefore to describe the views of Muhammadiyah on liberalism by providing advanced features of thought among the contemporary Islamic movement in Indonesia and provides six values of liberalism in Muhammadiyah. Furthermore, this study reveals that there are four movements. The first is fundamentalist Islam which applies fundamental teachings of Islam based on Islamic tenets and faith. The second one neo-traditionalist Islam which sees Islam is in harmony with the development of the local culture, so it greatly appreciates multiculturalism. The third one is neo-modernism which lies its nature on adjusting the understanding Islamic religious with new developments in science and modern technology. The fourth one is Islamic liberal considering tarnishing Islam because the Scriptures are regarded as a product of culture so that the seriousness becomes zero. Besides, the values of liberalism in Muhammadiyah encompass (1) the attitude of rejection of theocracy (tyrant), (2) attitude towards democracy, (3) respect for women's rights, (4) respect for the rights of Non-Muslims, (5) freedom of thought and (6) progress.
\end{abstract}

Keywords: Muhammadiyah, liberalism, Indonesia

\section{INTRODUCTION}

Nowadays the emergence of contemporary Islam started to spread in a variety of faces, starting from the release of the books that discuss those ideas up to the scientific forum examined that presented in different academic environment. These symptoms appear in response to the advances that resulted in the existence of various changes in society, social order, both regarding ideology, political, social, cultural and so forth. Many of these changes seem to have distanced people from the religious values which in turn raised the issue.

From the above phenomenon finally comes an issue again when the presence of a social control that is capable of controlling the movement of such a fundamental change. While the settled Western thought, methodology turned out to be factually more easily accepted and applied in life, because it is supported by the strength of the structural or cultural nature. While Muslims accepting West thought, model find out there is any discrepancy, both psychological, sociological or political. Yet, since the applicative concept of Islam has not yet been realized, it is then hardly forced to follow the concepts that are perceived by most of nonMuslims, Christian, with the appearance of Jewish Agency mission [1].

The dynamics of Islamic thought in Indonesia this decade lately, especially those that thrive on young intellectuals actually stem from major mainstream Islamic thought renewal movement, especially when there is a mapping between the thought of "tradition and modernity" (al-turâts wa al-hadâtsah) could not be released from the developing of Arabic thought. The term "tradition and modernity", which was carried out by Mohammed Abed al-Jabiri, used in the discourse of contemporary Arab thought refers to the term varied idiomatic, usually used al-turâts wa alhadâtsah. Literally, turâts means a legacy or heritage (heritage, legacy), namely in the form of abandoned/scientific wealth bequeathed by the previous ones (al-qudama). The term is a genuine product of contemporary Arab discourse, and there is no exact equivalent in classical Arabic literature to represent the term.

Terms such as al-'adah (habits), 'urf (custom) and Sunna (the ethos of the Apostles) even though it contains the meaning of tradition, but does not represent what is meant by the term turâts. As well as in the literature of European languages, there is no proper variable. According to Jabiri, legacy and heritage in the United Kingdom, or patrimony and legs in French does not represent what the Arabs think about turâts.

The emergence of the phenomenon of Islamic doctrine that is very diverse, certainly has the background of its appearance, the limitations and characteristics of each movement of thought of Islam that emerged in Indonesia. Each has a pretty face and complexion. The following advanced features of thought among the contemporary Islamic movement:

\subsection{Islamic Fundamentalist}

The term Islamic fundamentalist is meant that Islam, in understanding and practice, rests on incidental or fundamental rights. Understanding in such a literary sense, fundamentalist Islam is a movement or understanding the fundamental teachings based on Islam, especially related to Islamic tenets and faith. In terms of literary, then all streams or understanding that makes the tenets of the faith and the teachings of Islam as a major, then they belong in this group. Even three major streams in the world, such as Sunni, Syiah and Ahmadiyah also make the teaching as the 
basis for a foothold in the religion. In addition, in the context of Indonesia, the two largest religious doctrine, such as the NU and the Muhammadiyah was also included in the literary sense.

Actually, the term appears among the Christian community that developed in the West, that this religious understanding is more fundamental nature, narrow and dogmatic. In the West, the group emerged as a reaction to the theory of human evolution proposed by Charles Darwin. Among the Islamic world, the term fundamentalist is more addressed to the hardline Islamist groups. Understanding the fundamentalists, in terms of the term even finally having psychological and sociological charge, and different notions of fundamentalists are literary. In Muslim societies, there is a relation to the issue of political conflict, social, political and cultural. The term fundamentalism at certain imagery, eventually leading to the extremism, fanaticism, terrorism or even realize or maintain its religious beliefs, even those tend to perform acts of violence.

\subsection{Neo Traditionalist Islam}

The emergence of a group of traditionalists, in the context of Indonesian Islamic thought, came up before the advent of the term neo-traditionalism thinking. As a tradition, from neo-traditionalism see that Islam is in harmony with the development of the local culture, so greatly appreciate multiculturalism. Neo-traditionalism tends to be on the local culture where Islam flourished (living). Arabic culture also became local, so that Arab Islamic solely an expression of Arabic culture rather than Islam itself. In addition, people with this view tend to think and be inclusive (open) on the social reality, as put forth Marzuki Wahid.

In terms of having state, this group saw that Islam have absolutely no form of State. The most important for Islam is the civic ethic. The reason is that Islam does not recognize the concept of a definitive rule. Similarly, in the event of the succession of power, Islam has no fixed form. Sometimes wearing istikhlaf, bai'at (Rapture), and experts such as aqdi wal halli put forward Ahmad Amir Aziz, in his NeoModernism of Islam in Indonesia. To that end, Indonesian Muslims should be able to receive the national awareness and insight as objective reality and need not be disputed.

\subsection{Neo Modernist}

Formerly, actually appears the term modernist Islam, which brought Islam to religious modernization. Similar to what was happening in the West, which took place in the Islamic world, the Islamic modernist movement appeared in order to adjust the understand-understand Islamic religious with new developments brought about advances in science and modern technology. The emergence of this movement is as response to a variety of underdevelopment experienced by Muslims in the fields of economy, education, culture, politics and more. This circumstance is considered not in line with the spirit of the teachings of Islam, described that Islam's push towards progress, uphold science, which is the estuary carries the benefit to the life of mankind. But the fact is precisely the Muslims through backwardness and setbacks. This is what brings out the inner angst for the modern movement's thinkers to try to understand the Islamic teachings are contextually that can manifest in people's lives.

Then, later came up the term Neo-Modernist Islamic which roughly began to appear in the 1970s. At this time the pattern of Islamic thought was infected with symptoms starting new or renewal of what was later called the "neomodernism". The figure of Cak Nur, for example, is regarded as the locomotive of the opener for the spread of neo-modernist discourse of Islam in Indonesia. This movement seemed to put Islam as a system and order value must be earthed in accordance with the interpretation as well as the demands of the increasingly dynamic. His character is more inclusive, moderate, and acknowledge the existence of the pluriform of life, thus forming the religious attitudes that respect the incidence of differences.

\subsection{Islamic Liberal}

After the Neo-Modernist Islamic movement experienced a metamorphosis, it appears that Islam is increasingly developing along with the development of the model of thought, neither of which appear in the Islamic world and the West. This also happens in Indonesia, that after more than 30 years the movement of thought model of neomodernism got place in the constellation of Islamic thought in Indonesia, then came up the movement of "Islamic liberal ". The term appears when Greg Barton calls it in his book: Gagasan Islam Liberal di Indonesia (the idea of Liberal Islam in Indonesia). About 2001 publication of liberal Islam "schools of thought", this virgin soil does seem systematically, which then managed to Jamaah Islam Liberal (JIL).

\section{THE DISCOURSE OF LIBERALISM IN THE BELIEF OF MUHAMMADIYAH}

Muhammadiyah is Islamic renewal movement founded by KH. Ahmad Dahlan on 8th Dhulhijjah 1330 h. coincides with the date, November 18, 1912 in Yogyakarta. The Organization has pioneered a new movement in Islam, i.e. understanding "Dinul Islam" with renewed vigor, with the new paradigm that is adapted to the times which is always changing undoubtedly. There are five pillars of Muhammadiyah movement [2]., which is believed to be the basic stance of the charity efforts of Muhammadiyah, an Islamic movement, the Muhammadiyah as indication of the spread movement amar makruf nahi munkar thought, tajdid movement, as the mobilization of good deed, and as a nonpolitical practical movement. The implications of his position as movement occurs, then the development of Islamic Tajdid thought in the body of this Organization for a long-time literature in lively called "Modernized Islam". Later among the Muhammadiyah even appeared a new term, i.e. Islam transformative, carried by Muslim Abdurrahman, the Muhammadiyah which generation look closer to the Nahdhiyyin, though they later recorded as the Governing Board of PP Muhammadiyah Chairman of the 
empowerment Institute, laborers, farmers and fishermen, (Institute for which he most unscientific) in Muhammadiyah environment.

The values of liberalism in Muhammadiyah if measured using the Kurzman [3], based on the theory of 6 (six) states of mind namely: a) the attitude of rejection of theocracy (tyrant), b) attitude towards democracy, c) respect for women's rights, d) respect for the rights of Non-Muslims, e) freedom of thought, and f) progress, which then most of the points were there becoming the official formulation, as well as applied in Muhammadiyah. This can be confirmed for example by the material contained in the outline of The Introduction of Muhammadiyah Statute, the identity of the Muhammadiyah, MKCH (basic principles and ideals of life), and in the document of Muhammadiyah ideological al-Mar'ah Fi al-Islam, as well as in the HPT (a set of the verdict) of Muhammadiyah [4].

To conduct the study comprehension, need to put forward a few points from the ideological, as follows:

\subsection{Introduction to Muhammadiyah Statute}

Muhammadiyah is an organization, a tool of struggle to achieve a goal. Muhammadiyah was established above (based on) and staple to realize the mind-a mind which is the subject of the principles/establishment and his fight for life. The main thoughts/principles/establishment were the principles of its identity.

On the subject of basic principles of the establishment in question is the right to live and the value of Muhammadiyah in ideology. Those all had been described in Introduction of Muhammadiyah Statute.

\subsection{The History of the Introduction of Muhammadiyah Statute}

a. Introduction of Muhammadiyah Statute was created by the late Ki Bagus H. Hadikusumo, (Chairman of the Executive Board of the Muhammadiyah in 1942-1953), with the help of some of his friend. Putting it together was started in 1945 and passed in Council 1951 tanwir.

b. The Introduction of Muhammadiyah Statute becomes important background which functions needs to be understood.

c. The background is starting to seem/feel the fuzziness in Muhammadiyah as a result of the process of life after more than 30 years, characterized by:

1) The recessive of growth and development of the soul/ spirit of Muhammadiyah by physical development.

2) The inappropriate influx of influences from outside has become stronger.

d. The introduction of Muhammadiyah Statute is the result of Ki Bagus's expression highlighting KH. A. Dahlan's ideas whose awareness in the fight for his life, resulting the establishment of Organization of Muhammadiyah.

e. Ki Bagus wished the Introduction of Muhammadiyah Statutes could be maintained and guarded, or purification so that can always be clearly and explicitly known: what and how recently it was. Introduction of Muhammadiyah Statute

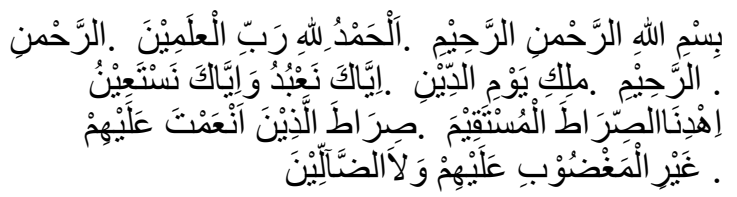

In the Name of Allah, the Most Beneficent, the Most Merciful. All the praises and thanks be to Allah, the Lord of the 'Alamin (mankind, jinns and all that exists). The Most Beneficent, the Most Merciful. The Only Owner (and the Only Ruling Judge) of the Day of Recompense (i.e. the Day of Resurrection). You (Alone) we worship, and You (Alone) we ask for help (for each and everything). Guide us to the Straight Way. The Way of those on whom You have bestowed Your Grace, not (the way) of those who earned Your Anger (such as the Jews), nor of those who went astray (such as the Christians) (QS. Al-Fatihah: 1-7).

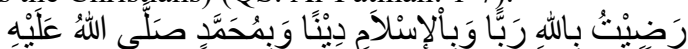

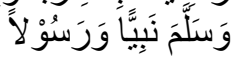

"I hereby pronounce Allah as my God, Islam as my faith and Muhammad as the prophet and messenger of Him".

Amma ba'du, that indeed the divinity is exclusively the right of God. Believe in, worshipping as well as obeying God is the only provision which is obligatory upon every living creature, especially humans.

Living in society is Islamic tradition (law of qudrat iradat) of God over human life in this world.

A prosperous society, secure, peaceful, prosperous and happy life is simply materializing above justice, honesty, brotherhood and mutual, co-favor by based on law that truth, escape from the influence of the devil and the lust.

The religion of God brought by the Prophet and taught by wise and Holy-spirited, is the only legal principle in the society and at their best.

Upholding the law rather than any law, is absolute liability for every man who pleaded with the Lord to Allah.

Islam is a religion of God brought by all Prophets, from Adam to Prophet Muhammad, and taught to his people each to get the happy life of the world and the hereafter.

One day, to create a happy society and as such the wealthy on top of that, each people, especially Muslims, people who believe in God and the day after, must follow the lead of all the holy prophets: worshipping for God and seeking to have all been very zealous gather strength-and using it to manifest that society in the world, with a pure intentionsincere and sincere because God purely and simply expect the grace of God and his sheer pleasure, as well as having a sense of responsibility in the presence of God over all the acts, after all have to be patient and rely all difficulties or hardships that befell him, or obstacles that hinder his work, with full expectation of protection and the help of God Almighty.

To carry out the realization of such a society, with the blessing and mercy of God are encouraged by the word of God in the Qur'an:

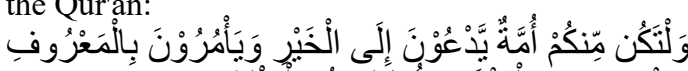

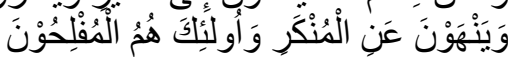


Let their arise out of you a group of people inviting to all that is good (Islam), enjoining Al-Ma'ruf (i.e. Islamic Monotheism and all that Islam orders one to do) and forbidding Al-Munkar (polytheism and disbelief and all that Islam has forbidden). And it is they who are the successful (QS Ali-Imran: 104).

On the 8th Dzulhijah 1330 Hijri, November 18, 1912 Miladiyah, the late KH. A. Dahlan founded an organization as "Islamic movement" with the name "MUHAMMADIYAH" compiled by the assemblies (parts of), following new era based on "Syura" led by wisdom in a consultative or Procuring.

Overall, it is necessary to perform the duty practicing God's commandments and following the tradition of his Messenger, Prophet Muhammad, in order to get the gifts and his bless in world and the hereafter, and to achieve a society that is wealthy and happy, accompanied by delicious and rich grace of God-affluent, so it is:

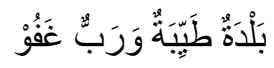

The country is beautiful, clean and prosperous under the protection of God Forgiving.

Hence, through Muhammadiyah hopefully all Moslems can be delivered to the gate of heaven "Jannatun Na'im" with bless of God, the Most Beneficent, the Most Merciful.

\section{THE IDENTITY OF MUHAMMADIYAH}

\subsection{The Notion and Function of the Identity of Muhammadiyah}

The identity of Muhammadiyah is not a new thing. It is something that blends in Muhammadiyah which comes to be the characters of Muhammadiyah that characterize it after all. The identity of the Muhammadiyah comes from the excavation of philosophy which results formulation of the fine points of mind, the basic principles of the struggle, the method of struggle, action steps and gestures of KHA Dahlan; the disciples and the Muhammadiyah activists in the beginning. Thus, in the formulation of the various things that are not in accordance with the ideas, ideals and Belief struggles of KHA Dahlan and his disciples had been cleaned. That formulation has been summarily purged from things that are not in accordance with the teachings and example of Prophet Muhammad PBUH.

\subsection{The Function of Muhammadiyah's Identity}

The function of Muhammadiyah's identity was to become the cornerstone, the guidelines and the handle of the leaders, activists and members of the Muhammadiyah in administering organizations, movements and charitable efforts in order not to be swayed by outside influences and remain istiqomah to ideals and struggle of Muhammadiyah and how to fight for his ideals. It means that it is not affected by other religious doctrines, ideologies of others, other religious schools, the ism's, political movements, lifestyle, culture and civilization of non-Moslems as well as nonMoslem way of thinking (a Western way of thinking such a secular, liberal, etc.)

\subsection{The Identity of Muhammadiyah Consists of Four Principles of Thoughts}

What is Muhammadiyah? Muhammadiyah Foundation and charity efforts of Muhammadiyah. Guidelines for charitable efforts and struggles of Muhammadiyah. The properties of the Muhammadiyah.

\subsection{The History of Muhamamdiyah's Identity}

Raw thought about "Muhammadiyah Identity" is a result of the decision to the Congress at 35 (Procuring a half century) in 1962 in Jakarta. The concept originally derived from lectures KH Faqih Usman in PP Muhammadiyah's leadership, the period 1959-1962, under Chairman H.M. Yunus Anis. The lecture was titled "what the hell Was that?" then follow up team of framers, then discussed in Tanwir on 25-28 August 1962 and finally decided on the $35^{\text {th }}$ Procuring.

\subsection{The Founding Fathers of Muhamamdiyah's Identity}

The initial concept of identity of Muhammadiyah was postulated by $\mathrm{KH}$ Faqih Usman in a leadership course organized by the PP Muhammadiyah and followed by the leader of the Muhammadiyah movement throughout Indonesia in Ramadan $1381 \mathrm{H}$ in Yogyakarta. At that time the KH Faqih Usman gave his lecture with the title "What is Muhammadiyah?"

The concept was later refined by a team whose members are: a) KH. Faqih Usman, b) Prof. H.Farid Makruf, c) H. Djarnawi Hadikusumo, d) M. Djindar Tamimy, e) Dr. Hamka, f) KH. R. Muhd Wardan Diponingrat, g) M. Saleh Ibrahim, h) KH. Faqih Usman, and i) Prof. H.Farid Makruf.

\subsection{Background}

The background coloring the birth of the Identity of Muhammadiyah is the inclusion of thought and politics in ways to manage and drive the Muhammadiyah after Masyumi (Indonesia Muslims Advisory Council) dissolved and the belief that people in the Islamic political party, returned to the Muhammadiyah.

\section{CONCLUSION}

Liberalism has been talked over in the perspective of Islam and Muhammadiyah organization. Muhammadiyah provides six values of liberalism in Muhammadiyah. The first is fundamentalist Islam which applies fundamental teachings of Islam based on Islamic tenets and faith. The 
second one neo-traditionalist Islam which sees Islam is in harmony with the development of the local culture, so it greatly appreciates multiculturalism. The third one is neomodernism which lies its nature on adjusting the understanding Islamic religious with new developments in science and modern technology. The fourth one is Islamic liberal considering tarnishing Islam because the Scriptures are regarded as a product of culture so that the seriousness becomes zero. Besides, the values of liberalism in Muhammadiyah encompass (1) the attitude of rejection of theocracy (tyrant), (2) attitude towards democracy, (3) respect for women's rights, (4) respect for the rights of NonMuslims, (5) freedom of thought and (6) progress.

\section{REFERENCES}

[1] A. Muhlis, Peta Gerakan Pemikiran Kontemporer di Indonesia, handout, seminar Islam Kontemporari, 1997.

[2] Amin Rais. Lima pilar Khitah Muhammadiyah, seminar paper "Muhammadiyah menyongsong Muktamar Muhammadiyah 43, 1995.

[3] Charles Kurzman,. "Introduction: Liberal Islam and its Islamic Context”. in Liberal Islam: A Source Book, Charles Kurzman, ed. New York: Oxford University Press.

[4] PP Muhammadiyah, Himpunan Putusan Tarjih 